\title{
Members' Page
}

\section{Meetings}

On Wednesday, March 24th at $6 \mathrm{pm}$, Philip Wayre will show a film on otters and give an illustrated talk on the work of the Otter Trust. A wine and cheese supper will be served.

On Wednesday, June 16th the Annual General Meeting will be presided over by Lord Zuckerman. Sir David Serpell, Chairman of the Nature Conservancy Council, will speak on wildlife conservation in Britain and the problems arising from the British Government's implementation of the international convention on trade in endangered species. A 50-minute colour film of Gorillas, by Dieter Plage, will be shown by courtesy of Aubrey Buxton and Anglia Television.

A wine and cheese supper will be served, and members and friends will be able to walk in the zoo gardens by kind invitation of the Zoological Society. Both meetings will be in the Zoo Meeting Rooms, Regent's Park, at 6 pm. Tickets for the meetings only (free) and for the meetings with supper (£2.00) obtainable from the FPS office-an addressed envelope for these would be gratefully received.

\section{Back Numbers of Oryx}

A bound set of Oryx vols 1-5 (1950-1960) is for sale; also a complete set 1950-1975, with vols 1-6 bound. Please send offers to FPS office by June 30th.

The office would be glad to receive copies of the following issues of Oryx which are in short supply: vols. $6: 1 ; 7: 2 ; 9: 1,3,4 ; 10: 3$.

\section{Indian Ocean Tour}

There are still a few last-minute places on the tour to Madagascar, Réunion and Mauritius, April 14th-May 3rd. Write to FPS office.

\section{Subscriptions}

Many members have already paid their 1976 annual subscription. We would be very grateful if those who have not done so would do it immediately to save the expense of an individual reminder. The annual subscription is now $£ 5$.

\section{Conference on Captive Breeding}

The second World Conference on Breeding Endangered Species in Captivity will be held at the London Zoo, July 6th-8th, 1976, as already announced. Registrations should reach Dr M. Brambell, at the Zoological Society by March 31st.

\section{The next Oryx}

The next issue of Oryx will be published in July. 